\title{
Multivariate regression analysis of the 3D composites with electroconductive properties for sensors
}

DOI: $10.35530 / I T .071 .04 .1767$

\section{ABSTRACT - REZUMAT}

\section{Multivariate regression analysis of the 3D composites with electroconductive properties for sensors}

This work presents several aspects of the multivariate regression importance in the analysis of the parameters (dependent and independent variables), which characterize the 3D composite materials with electroconductive properties. The experimental part was developed by using fabrics from $100 \%$ cotton, $100 \%$ polyamide, and $100 \%$ polypropylene fabrics to obtain the electroconductive and electromagnetic properties based on classical technologies and $3 D$ digital printing advanced technology. The fabric was printed with paste containing zinc, copper, nickel, iron oxide II, III, silver, and Graphite microparticles content. Initially, the fabric has coated using the standard technologies implemented by padding (Flame Retardants), scraping, and $3 D$ printing advanced technology for submission of the ESD filaments. For flame retardancy properties, the fabric has been impregnated in a solution of $50 \%$ Aflamit and dried at a temperature of $120^{\circ} \mathrm{C}$ for 3 minutes.

Keywords: composites, textile, electroconductive, resistance, microparticles, sensors

\section{Analiza de regresie multivariată a compozitelor 3D cu proprietăţi electroconductive pentru senzori}

Această lucrare prezintă câteva aspecte privind importanţa analizei parametrilor (variabile dependente şi independente), care caracterizează materialele compozite 3D cu proprietăţi electroconductive. Pentru realizarea experimentelor au fost utilizate ţesături din 100\% bumbac, 100\% poliamidă şi 100\% polipropilenă pentru obţinerea proprietăţilor electroconductive şi electromagnetice pe baza procedeelor clasice şi avansate de imprimare digitală 3D. Tesăturile au fost imprimate utilizând paste cu conţinut de microparticule de zinc, cupru, nichel, oxid de fier II, oxid de fier III, argint şi grafit. Iniţial, ţesătura a fost tratată prin tehnologiile clasice de fulardare (ignifugare), raclare şi, în final, prin procedeul avansat de imprimare digitală $3 D$ pentru depunerea filamentelor ESD. Pentru ignifugare, materialul textil a fost impregnat în soluţie de Aflamit $50 \%$ şi uscat la o temperatură de $120^{\circ} \mathrm{C}$ pentru 3 minute.

Cuvinte-cheie: compozit, textil, electroconductiv, rezistenţă, microparticule, senzori

\section{INTRODUCTION}

Multivariate regression is a method used to evaluate the relationship between more than one independent variable (predictors) and more than one dependent variable (responses).

$$
y_{1}, y_{2}, \ldots, y_{n}=f\left(x_{1}, x_{2}, \ldots, x_{m}\right)
$$

The multivariate linear regression is an extension of multiple linear regressions to analyze possible linear relationships between input and output variables [1]. However, this technique was used to explain the feasibility of two-way prediction by developing models for fiber and yarn and reverse models relating yarn to fiber using multivariate methods simultaneously [2] and to trace metals in textile effluents in relation to soil and groundwater [3]. In this paper, the multivariate analysis [4-7] is used to investigate the influence of the independent and dependent variables in the electroconductive textile development. In comparison with multiple regressions, where it is necessary, only one predictor and one response in a multivariate regression model are more than on predictors and more than one response [8].

The conductive textiles can be obtained by coating with organic conductive polymers such as polyaniline (PANI), polypyrrole (PPy), and polythiophene (PTh) derivatives [9-10]. The selection of the method to produce conductive textiles (yarns, fibers, fabrics) depends on the type of textile used to be coated, dimensions, and surface properties. However, the superior conductive composites can be obtained using coating dispersions based on carbon (carbon nanotubes (CNTs) or graphene). Besides, some researches indicate that the conductive surface can be obtained by coating graphene oxide onto traditional textiles (silk or polyamide) and followed by thermal reduction [11]. Another direction is on using the nonfunctionalized CNTs, with length over than $500 \mu \mathrm{m}$, 
mixed with an amino-functionalized sol-gel precursor for coating textile surfaces to obtain the textile composite with surface electrical resistance around $9.5 \times 10^{2}$ [12]. Concerning the ESD (Electrostatic discharge) or PLA (Polylactic acid) filament deposition on textile to obtain 3D composites, already exist several approaches adopted by researchers for dualmaterial fused filament fabrication for 3D printing electronic components and circuits with conductive thermoplastic filaments [13-15]. 3D printing technology of ESD/PLA filaments, made using cutting-edge multi-wall carbon nanotube technology [16], is cheap and very accessible to a broad public. However, the inconvenience in printing 3D ESD filaments comes from the low surface adhesion of rigid ESD or PLA filament [17] to the flexible textile surface. The non-uniform adhesion to the textile surface can generate real problems due to the temporary effect or low traction resistance on the warp, weft, and $45^{\circ}$ directions [21]. $3 \mathrm{D}$ printing of the polymer filaments directly on fabrics is a thermal welding method in which the polymer as an adhesive and textile material as an adherent are joining during the printing process [17-18]. The adhesion between textile and 3D filament can be influenced by the textile surface and temperature [17-18].

\section{EXPERIMENTAL PART}

In the experimental part there have been carried out experimental samples using cotton fabric (BBC) $100 \%$, polyamide (PA) 100\%, and polypropylene (PP) 100\%, with electroconductive properties and electromagnetic based on traditional technologies and 3D digital printing technology. In order to achieve the 28 samples functionalization experimental fabrics by submission of microbead particle of nickel (Ni), copper $(\mathrm{Cu})$, iron oxide II, III $\left(\mathrm{Fe}_{3} \mathrm{O}_{4}\right)$, silver $(\mathrm{Ag})$, graphite (C) and zinc $(\mathrm{Zn})$, have been used for the classic technologies implemented by padding (Flame Retardants), direct printing (polymeric pasta with a microbead particle of $\mathrm{Zn}, \mathrm{Cu}, \mathrm{Ni}, \mathrm{Fe}_{3} \mathrm{O}_{4}$, Ag, and Graphite), scraping, and advanced technology for submission by the $3 \mathrm{D}$ digital printing on the basis of the filaments ESD. For the flame retardants, the fabric has been impregnated in a solution of $50 \%$ Aflamit and dried at a temperature of $120^{\circ} \mathrm{C}$ for 3 minutes.

To obtain electroconductive properties there were used to print, the polymers, such as polyethylene glycol (PEG), polyvinyl alcohol (PVA), gelatine, and metallic microparticles (Ag, $\mathrm{Zn}, \mathrm{Fe}_{3} \mathrm{O}_{4}$, graphite $(\mathrm{C})$. In the experimental part, we developed 28 conductive fabrics through direct printing (direct printing and scraping) with paste based on water, binders (PEG and/or PVA) and microparticles of $\mathrm{Cu}$ (V1-Cu $<45$ $\mu \mathrm{m}$; V2-Cu < $75 \mu \mathrm{m})$; V3-Cu = 14-25 $\mu \mathrm{m}), \mathrm{Zn}, \mathrm{Fe}_{3} \mathrm{O}_{4}$, $\mathrm{Ni}(<50 \mu \mathrm{m}, \mathrm{Ag}(\mathrm{V} 1-\mathrm{Ag}<45 \mu \mathrm{m}$; V2-Ag = 2-3.5 $\mu \mathrm{m})$ and graphite $(\mathrm{C})$ followed by drying at a temperature of $19^{\circ} \mathrm{C}$ for 20 hours and the condensation for $3 \mathrm{~min}-$ utes for functionalization by increasing the static or electroconductive character. Table 1 presents the surface resistance (Rs $[\Omega]$ ) and conductance (G $[S]$ )

SURFACE RESISTANCE AND CONDUCTANCE OF THE SAMPLES FUNCTIONALIZED BY PRINTING WITH A POLYMERIC PASTE BASED ON DIFFERENT METALLIC MICROPARTICLES

\begin{tabular}{|c|c|c|c|c|c|c|c|c|c|c|c|c|c|c|c|}
\hline Sample & $\mathrm{Ni}$ & $\begin{array}{l}\text { V1 } \\
\dot{\mathrm{Cu}}\end{array}$ & $\begin{array}{l}\text { v2 } \\
\dot{\mathrm{Cu}}\end{array}$ & $\begin{array}{l}\text { v3 } \\
\dot{\mathrm{Cu}}\end{array}$ & $\begin{array}{c}\mathrm{V1} \\
\overline{\mathrm{Ag}}\end{array}$ & $\begin{array}{c}\text { V2 } \\
\overline{\mathrm{Ag}}\end{array}$ & $Z n$ & $\mathrm{Fe}_{3} \mathrm{O}_{4}$ & Graphite & PEG & PVA & Gelatin & $\mathrm{H}_{2} \mathrm{O}$ & $\begin{array}{l}\text { Rs } \\
(\Omega)\end{array}$ & $\begin{array}{c}\mathbf{G} \\
(\mathbf{S})\end{array}$ \\
\hline 1 & & & & & & & & & $x$ & $x$ & $x$ & & $x$ & $10^{11}$ & $10^{-11}$ \\
\hline 2 & & & & & & & & $x$ & & & $x$ & & $x$ & $10^{7}$ & $10^{-7}$ \\
\hline 3 & & & $x$ & & & & & & & & $x$ & & $x$ & $10^{12}$ & $10^{-12}$ \\
\hline 4 & $x$ & & & & & & & & & & $x$ & & $x$ & $10^{3}$ & $10^{-3}$ \\
\hline 5 & & & & $x$ & & & & & & & $x$ & & $x$ & $10^{7}$ & $10^{-7}$ \\
\hline 6 & & $x$ & & & & & & & & & $x$ & & $x$ & $10^{3}$ & $10^{-3}$ \\
\hline 7 & & & & & $x$ & & & & & & $x$ & & $x$ & $10^{8}$ & $10^{-8}$ \\
\hline 8 & & & & & & $x$ & & & & & $x$ & & $x$ & $10^{3}$ & $10^{-3}$ \\
\hline 9 & & & & & & & $x$ & & & & $x$ & & $x$ & $10^{12}$ & $10^{-12}$ \\
\hline 10 & $x$ & & & & & & & & & & $x$ & & $x$ & $10^{3}$ & $10^{-3}$ \\
\hline 11 & & $x$ & & & & & & & & & $x$ & & $x$ & $10^{4}$ & $10^{-4}$ \\
\hline 12 & & & & & & $x$ & & & & & $x$ & & $x$ & $10^{3}$ & $10^{-3}$ \\
\hline 13 & & $x$ & & & & & & & & & $x$ & $x$ & $x$ & $10^{4}$ & $10^{-4}$ \\
\hline 14 & & & $x$ & & & & & & & & $x$ & $x$ & $x$ & $10^{9}$ & $10^{-9}$ \\
\hline 15 & & & & & & $x$ & & & & & $x$ & $x$ & $x$ & $10^{3}$ & $10^{-3}$ \\
\hline 16 & & & & & & & & $x$ & & & $x$ & $x$ & $x$ & $10^{7}$ & $10^{-7}$ \\
\hline 17 & & & & $x$ & & & & & & & $x$ & $x$ & $x$ & $10^{10}$ & $10^{-10}$ \\
\hline 18 & & & & & & & & $x$ & & & $x$ & $x$ & $x$ & $10^{8}$ & $10^{-8}$ \\
\hline
\end{tabular}


for samples. In table 1, for samples 21-28 it has been used the same type of conductive paste based of PVA, $\mathrm{H}_{2} \mathrm{O}$ and Ni microparticles but it has been used different textile support such as: for samples 21-22 has been used in a BBC fabric of $100 \%$, for samples 23-24 there have been used fabrics of PA $100 \%$ and samples 27-28 has been made using 100\% PP fabric. In the case of samples 21-28, changing the fiber composition of textile support has not influenced the conductivity or resistance to the surface, for the first 8 samples Rs being approximately $1 \times 10^{3}-1.1 \times 10^{3} \Omega$. For the first 9 experimental samples there have been investigated the rubbing (dry and wet wetting 69\%, the frictional force $9 \mathrm{~N}$ ) parallel to the warp direction in accordance with SR EN ISO 105-x12/2016 (table 2).

Table 2

\begin{tabular}{|c|c|c|c|c|}
\hline \multicolumn{5}{|c|}{ RESISTANCE TO DRY/WET RUBBING } \\
\hline Sample & $\begin{array}{c}\text { Metal } \\
\text { release } \\
\text { after dry } \\
\text { rubbing }\end{array}$ & $\begin{array}{c}\text { Metal } \\
\text { release } \\
\text { after wet } \\
\text { rubbing }\end{array}$ & $\begin{array}{c}\text { Resistance } \\
\text { to dry } \\
\text { rubbing }\end{array}$ & $\begin{array}{c}\text { Resistance } \\
\text { to wet } \\
\text { rubbing }\end{array}$ \\
\hline 1 & - & - & - & - \\
\hline 2 & 0.016 & 0.071 & 2 & 1 \\
\hline 3 & - & 0.3728 & - & $2-3$ \\
\hline 4 & 0.0015 & 0.0034 & $3-4$ & 3 \\
\hline 5 & 0.001 & 0.0071 & $4-5$ & 2 \\
\hline 6 & 0.0024 & 0.004 & $4-5$ & 3 \\
\hline 7 & 0.0022 & 0.0044 & $4-5$ & $4-5$ \\
\hline 8 & 0.002 & 0.0057 & $4-5$ & $3-4$ \\
\hline 9 & 0.0033 & 0.0078 & 4 & $1-2$ \\
\hline
\end{tabular}

The numeric values of physicomechanical parameters such as thickness $\delta(\mathrm{mm})$, the mass $M\left(\mathrm{~g} / \mathrm{m}^{2}\right)$, the permeability to air $\mathrm{Pa}\left(1 / \mathrm{m}^{2} / \mathrm{s}\right)$, the surface resistance $R s(\Omega)$ for 9 samples experimentally evaluated are presented in table 3 .

For the demonstration of the morphological changes which appear on the cotton fibers presented in table 4 there was analyzed the surface of the fabric using electron microscopy scanning with magnification X2000 for conductive samples (4, 6, 8, 0-initial) and samples treated with sweat acid, alkaline, respectively. Figure 1 presents the topographic analysis of the surface of the textiles on the basis of the electronic microscopy magnification $(4 \times)$, the surface of the initial

\begin{tabular}{|c|c|c|c|c|}
\hline \multicolumn{5}{|c|}{ SAMPLES 1-9 PHYSICO-MECHANICAL } \\
& \multicolumn{3}{|c|}{ PARAMETERS } \\
\hline Sample & $\begin{array}{c}\mathbf{M} \\
\left(\mathbf{g} / \mathbf{m}^{2}\right)\end{array}$ & $\begin{array}{c}\boldsymbol{\delta} \\
(\mathbf{m m})\end{array}$ & $\begin{array}{c}\text { Pa } \\
\left(\mathbf{l} / \mathbf{m}^{2} / \mathbf{s}\right)\end{array}$ & $\begin{array}{c}\text { Rs } \\
(\mathbf{\Omega})\end{array}$ \\
\hline 1 & 709 & 0.97 & 5.755 & $10^{11}$ \\
\hline 2 & 515 & 1.011 & 4.31 & $10^{7}$ \\
\hline 3 & 752 & 4.385 & 16.8 & $10^{12}$ \\
\hline 4 & 556 & 1.527 & 8.876 & $10^{3}$ \\
\hline 5 & 650 & 1.847 & 6.123 & $10^{7}$ \\
\hline 6 & 658 & 1.304 & 4.27 & $10^{3}$ \\
\hline 7 & 476 & 1.317 & 3.88 & $10^{8}$ \\
\hline 8 & 586 & 1.894 & 5.656 & $10^{3}$ \\
\hline 9 & 741 & 3.552 & 11.56 & $10^{12}$ \\
\hline
\end{tabular}

fabric (without metal content microparticle) (figure 1, a) and the surface of the fabrics microparticle of $\mathrm{Ni}$ (sample 4), Cu (sample 6) and the sample Ag (sample 8) (figure 1,b to $d$ ).

\section{RESULTS AND DISCUSSION}

The multivariate regression used to analyze the resistance and the thickness $(\delta)$, air permeability $(P a)$, and mass $(M)$. The value of multiple correlation $R$ is 0.944 (very close to 1 ), which means that is a strong positive relationship between $R s$ and $P a, \delta$, and $M$. In figures 2-5 are presented the 3D representations of the electrical resistance $(R s)$ in the function of the thickness $(\delta)$, mass $(M)$, air permeability $(P a)$, and resistance $(G)$ using MATLAB software.

For experimental parameters $(R s, M, \delta, P a)$ was performed an analysis of the correlation coefficient Pearson (2) between $R s$ and $P a, \delta, M$ :

$$
r_{x y}=\frac{\frac{1}{n} \sum(x-\bar{x})(y-\bar{y})}{s_{x} s_{y}}
$$

where $x, y$ represent the individual values of the variables $x$ and $y ; \bar{x}, \bar{y}$ represent the arithmetic mean of all the values of $x, y ; s_{x}, s_{y}$ represent the standard deviation of all values $x$ and $y$.

Analyzing the values of the correlation coefficients $r_{R_{s} P_{a}}(3), r_{R_{s} \delta}(4), r_{R_{s} M}(5)$, and $r_{R_{s} G}(6)$, it can be observed that between the surface resistance $(R s)$ and air permeability $(P a)$, mass $(M)$, thickness $(\delta)$ it is a positive direct proportionality relationship, and this indicate that an increase of the surface resistance

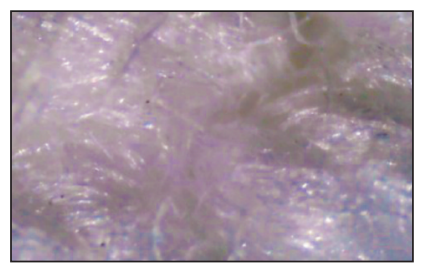

a

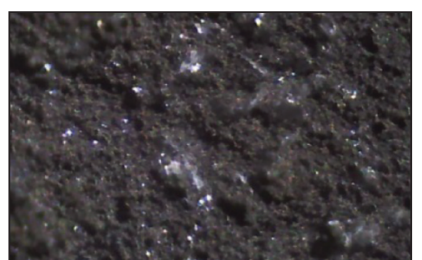

b

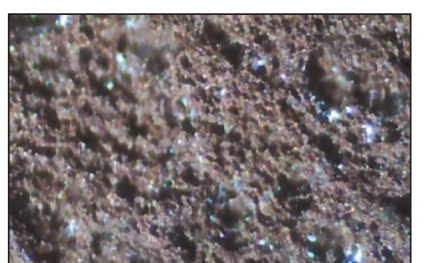

c

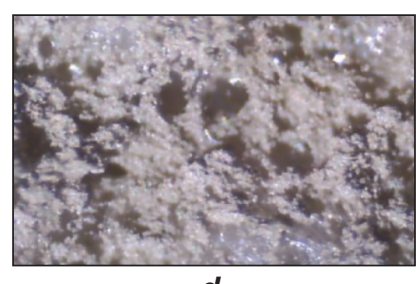

d

Fig. 1. Topographic analysis of the fabric surface based on electronic microscopy: a - fabric without microparticles submitted; $b$-sample no. $4 ; c$ - sample no. $6 ; d$-sample no. 8 


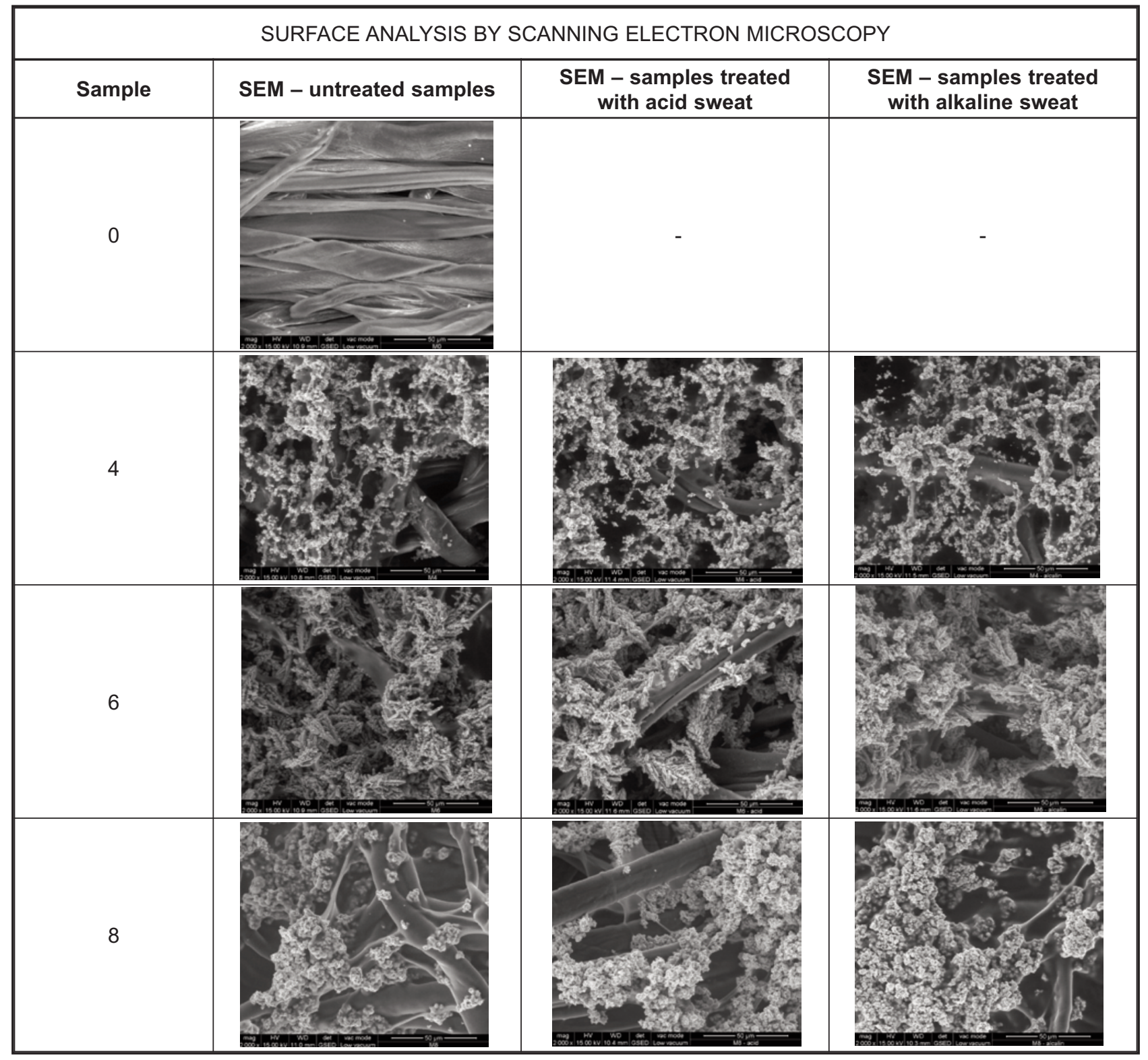

value can be generated through-thickness increasing, mass, and air permeability. Because the electrical resistance is inverse proportional with the electrical conductance (6), this means that higher air permeability leads to decreasing the conductivity, because of lower yarns density on weft or warp will not allow an excellent electrical conductivity.

This means that the increase of mass, air permeability, and thickness values determine an increase of the surface resistance values and by default, a decreasing of the values for conductance.

$$
\begin{aligned}
& r_{R_{s} P_{a}}=\left|\begin{array}{ll}
1.0000 & 0.8866 \\
0.8866 & 1.0000
\end{array}\right| \\
\Leftrightarrow & r 12_{R_{s} P_{a}}=r 21_{R_{s} P_{a}}=0.8866 \\
& r_{R_{s} \delta}=\left|\begin{array}{ll}
1.0000 & 0.9343 \\
0.9343 & 1.0000
\end{array}\right| \\
\Leftrightarrow & r 12_{R_{s} \delta}=r 21_{R_{s} \delta}=0.9343
\end{aligned}
$$

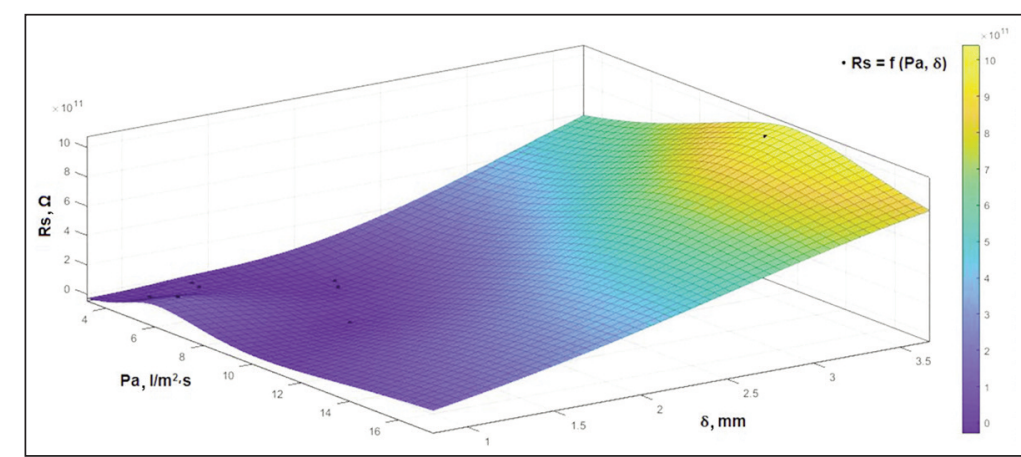

Fig. 2. 3D representation of the surface resistance according to the air permeability $(\mathrm{Pa})$ and thickness $(\delta)$

$$
(R s=f(P a, \delta))
$$

industroia textilla

$$
\Leftrightarrow r 12_{R_{s} G}=r 21_{R_{s} G}=-0.4016
$$




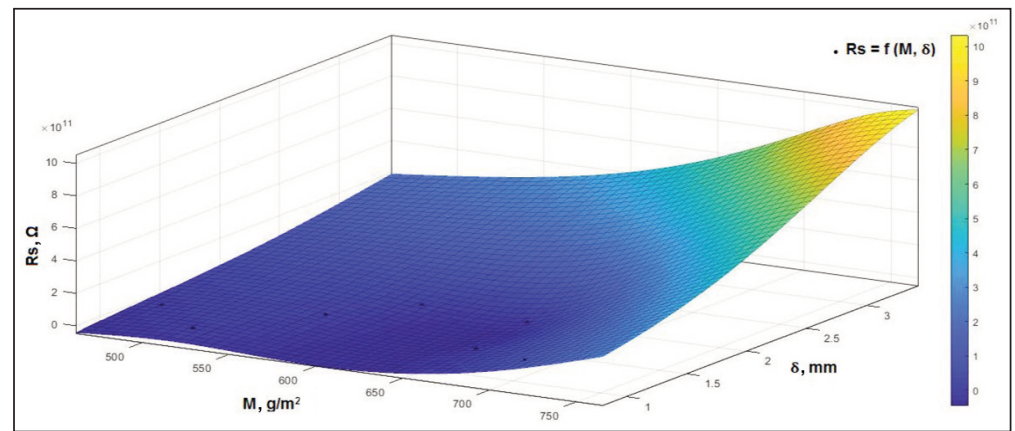

Fig. 3. 3D representation of the surface resistance (Rs) according to the mass $(\mathrm{M})$ and thickness $(\delta)$ $(R s=f(M, \delta))$

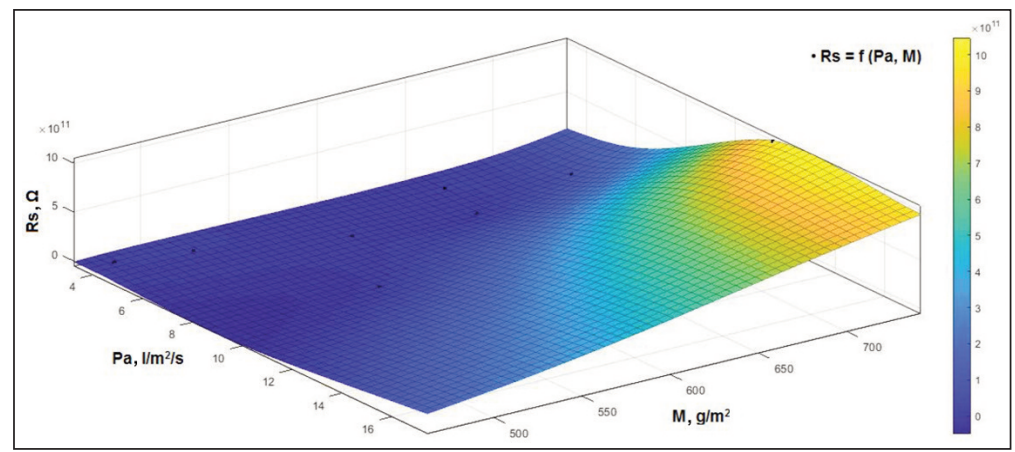

Fig. 4. 3D representation of the surface resistance (Rs) according to the air permeability $(\mathrm{Pa})$ and mass $(\mathrm{M})$ $(R s=f(P a, M))$

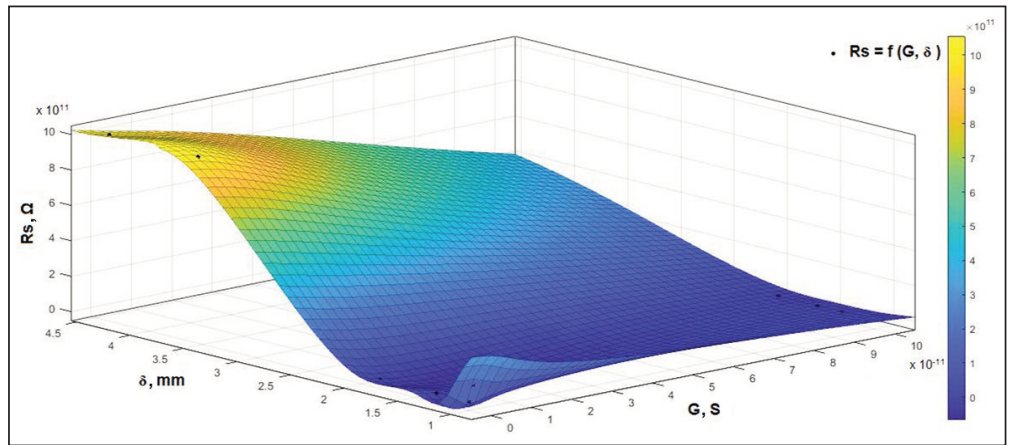

Fig. 5. 3D representation of the surface resistance (Rs) according to the thickness $(\delta)$ and conductance $(G)$

$(R s=f(\delta, G))$

\section{CONCLUSIONS}

For samples 4, 6, 8, 10-13, 15 and 20-28 it is evident that the surface resistance values are specific to the conductive materials $\left(10^{1}-10^{5} \Omega\right)$, and in case of the samples 2 , and 16 the surface resistance has the value $(R s=$ $10^{7} \Omega$ ) specific to static dissipative materials $\left(10^{6}-10^{12} \Omega\right)$.

Based on the analysis of the Pearson correlation coefficient, it can be concluded that mass, thickness, and air permeability are in a directly proportional relationship with the surface resistance and in an indirect proportionality relationship with the electrical conductivity. Due to the fact that the electrical resistance is inversely proportional to the electrical conductivity, it means that the increase of the air permeability, the mass, and the thickness will contribute to the decrease of the conductivity because on case of the fabrics with low density of yarns on warp and weft direction practically the concentration of metallic microparticles on the textile surface decreases and the electrical conductance will be reduced.

\section{ACKNOWLEDGEMENTS}

The research presented in this paper was prepared in the INCDTP laboratories. Funds support this work from $\mathrm{MCl}$, National Project "Materiale textile composite electroconductive pe bază de matrici polimerice 3D pentru sisteme senzoriale de monitorizare şi de atenuare a undelor electromagnetice (3D ELECTROTEX)", Contract PN 19170101.

\section{REFERENCES}

[1] Izenman, A.J., Multivariate regression, In Modern Multivariate Statistical Techniques, Springer, New York, NY, 2013, 159-194

[2] Fattahi, S., Ravandi, S.A.H., Taheri, S.M., Two $\square$ way prediction of cotton yarn properties and fiber properties using multivariate multiple regression, In: Journal of the Textile Institute, 2011, 102, 10, 849-856

[3] Manzoor, S., Shah, M.H., Shaheen, N., Khalique, A., Jaffar, M., Multivariate analysis of trace metals in textile effluents in relation to soil and groundwater, In: Journal of Hazardous Materials, 2006, 137, 1, 31-37

[4] Chamberlain, G., Multivariate regression models for panel data, In: Journal of econometrics, 1982, 18, 1, 5-46

[5] Zhang, X., Shi, X., Sun, Y., Cheng, L., Multivariate Regression with Gross Errors on Manifold-Valued Data, In: IEEE transactions on pattern analysis and machine intelligence, 2018, 41, 2, 444-458

[6] Chatfield, C., Introduction to multivariate analysis, Routledge, 2018

[7] Bing, X., Wegkamp, M.H., Adaptive estimation of the rank of the coefficient matrix in high-dimensional multivariate response regression models, In: The Annals of Statistics, 2019, 47, 6, 3157-3184

[8] Stockemer, D., Multivariate Regression Analysis, In: Quantitative Methods for the Social Sciences, Springer, 2019, 163-174

[9] Grancarić, A.M., Jerković, I., Koncar, V., Cochrane, C., Kelly, F.M., Soulat, D., Legrand, X., Conductive polymers for smart textile applications, In: Journal of Industrial Textiles, 2018, 48, 3, 612-642 
[10] Fu, K.K., Padbury, R., Toprakci, O., Dirican, M., Zhang, X., Conductive textiles, In: Engineering of HighPerformance Textiles, 2017, 305

[11] Zulan, L., Zhi, L., Lan, C., Sihao, C., Dayang, W., Fangyin, D., Reduced Graphene Oxide Coated Silk Fabrics with Conductive Property for Wearable Electronic Textiles Application, In: Advanced Electronic Materials, 2019, 5, 4, 1800648

[12] Trovato, V., Teblum, E., Kostikov, Y., Pedrana, A., Re, V., Nessim, G., Rosace, G., Designing of carbon nanotubes/cotton fabric composite for e-textiles: effect of carbon nanotubes length on electroconductive properties, In: Autex 2019: Textiles at the crossroads, 2019, 1-6

[13] Flowers, P.F., Reyes, C., Ye, S., Kim, M.J., Wiley, B.J., 3D printing electronic components and circuits with conductive thermoplastic filament, In: Additive Manufacturing, 18, 2017, 156-163

[14] Valino, A.D., Dizon, J.R.C., Espera Jr, A.H., Chen, Q., Messman, J., Advincula, R.C., Advances in 3D printing of thermoplastic polymer composites and nanocomposites, In: Progress in Polymer Science, 2019, 101162

[15] Bafleur, M., Caignet, F., Nolhier, N., ESD Protection Methodologies: From Component to System, Elsevier, 2017

[16] Kauppinen, E., Brown, D.P., Nasibulin, A.G., Jiang, H., Motta, A.M., Canatu Oy, Single, multi-walled, functionalized and doped carbon nanotubes and composites thereof, U.S. Patent 9,556,032, 2017

[17] Sanatgar, R.H., Campagne, C, Investigation of the adhesion properties of direct 3D, In: Microwaves, 2013, 7, 760-767

[18] Sanatgar, R.H., Campagne, C., Nierstrasz, V., Investigation of the adhesion properties of direct 3D printing of polymers and nanocomposites on textiles: Effect of FDM printing process parameters, In: Applied Surface Science, $2017,403,551-563$

\section{Authors:}

RALUCA MARIA AILENI, SILVIA ALBICI, LAURA CHIRIAC, IRINA-MARIANA SĂNDULACHE

National Research \& Development Institute for Textiles and Leather, 16 Lucretiu Patrascanu Street, 030508, Bucharest, Romania e-mail: silvia.albici@incdtp.ro; laura.chiriac@incdtp.ro; irina.sandulache@incdtp.ro

\section{Corresponding author:}

\section{RALUCA MARIA AILENI}

e-mail: raluca.aileni@incdtp.ro 